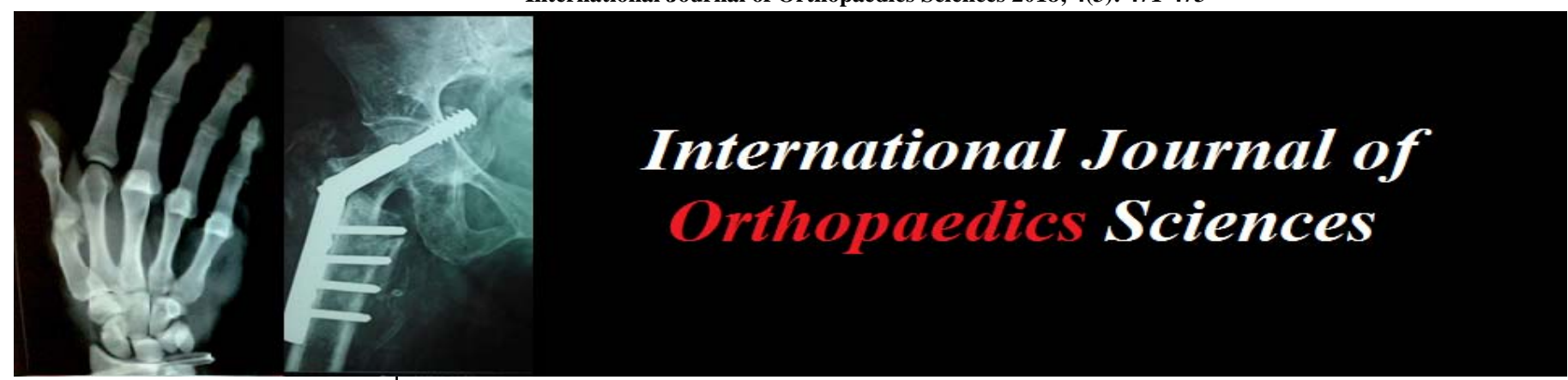

ISSN: $2395-1958$

IJOS 2018; 4(3): 471-473

(C) 2018 IJOS

www.orthopaper.com

Received: 25-06-2018

Accepted: 29-07-2018

Dr. Mohammed Abdul Bari

Assistant Professor, Department of Orthopedics, Mamata Medical

College, Khammam, Telangana, India

Dr. Sanjeev Chincholi

Professor of Orthopaedics,

Mamata Medical College,

Khammam, Telangana, India

\section{Occurrence of closed diaphyseal fractures of tibia in adults}

\section{Dr. Mohammed Abdul Bari and Dr. Sanjeev Chincholi}

DOI: https://doi.org/10.22271/ortho.2018.v4.i3i.81

\section{Abstract}

This study has been done to evaluate the results and complications of intramedullary interlocking nail for closed diaphyseal fracture of tibia in adults. 50 adult patients of fresh tibial shaft fractures treated surgically between December 2014 to march 2016. Among these $72 \%$ males and 28\% females and RTA was the common cause of fractures and right side accounts for $60 \%$. Surgery were performed with in 5 days average with interlocking intramedullary nail, trans tendinous approach was used in all 50 cases and reaming performed in all cases. All the fractures united with a union rate of $94 \%$. Radiological union was possible in 12.2 weeks, average range of motion in knee joint flexion was $135^{\circ}$, full ankle motion observed in $90 \%$ patients. There were one case of mal union, two cases of superficial infection, twelve cases of knee pain, one case of implant failure, one case of shortening, one case of Nonunion and two cases of delayed union. Functional results according to criteria by Klemm and Borner, 92\% of patients achieved good or excellent results, fair result obtained in one patient and one patient functional result was poor.

Keywords: Closed fracture, diaphyseal fracture, tibia, interlocking intramedullary nail

\section{Introduction}

Fracture shaft of tibia are increasing due to high velocity trauma such as RTA and rapid industrialization. Not only they are common, but often difficult to treat due to high incidence of complications such as compartment syndrome, vascular and neural injuries. Closed interlocking intramedullary nailing is accepted by most of surgeons, as the treatment of choice in diaphyseal fractures, Court Brown et al. ${ }^{[1]}$ studied closed intramedullary nailing, its use in closed fractures between 1985 and 1987. but it is associated with number of complications in the form of knee pain, delayed union, superficial infection. This Toivanen et al. ${ }^{\text {[2] studied }}$ anterior knee pain after intramedullary nailing of fractures of the tibial shaft. Most of the orthopaedics nails are made of $316 \mathrm{~L}$ stainless steel, the bending rigidity depends on the moment of inertia of the design which is proportional to the fourth power of the radius and the quantity of the material that is to say that the bending stiffness increases as the diameter and thickness of the nails increases ${ }^{[3]}$. This is a prospective study to evaluate the results of intramedullary interlocking nailing in closed diaphyseal fractures of tibia and to study the complications of intramedullary interlocking nailing of fractures shaft of tibia.

\section{Objectives}

To study the incidence of closed diaphyseal fractures of tibia in adult patients with respect to age, sex, occupation, fracture type and laterality of injury.

\section{Material and methodology}

A prospective study of results and complications following intramedullary interlocking nail in closed diaphyseal fracture of tibial shaft was done from December 2014 to march 2016. 50 patients with fracture shaft of tibia were selected for the study, there were 36 males $(72 \%)$ and 14 females (28\%), all the fractures were post traumatic, age between 20- 60 years with fresh transverse and short oblique closed fracture tibia shaft. Age less than 20 years, old fractures with complications like infections, delayed union, nonunion, mal union and compound fractures classified according to Gustillo Anderson system are excluded.
Dr. Sanjeev Chincholi Professor of Orthopaedics, Mamata Medical College, Khammam, Telangana, India 
Further descriptive data of the participants like name, age, sex, detailed history were obtained by interviewing the participants and clinical examination and necessary investigations were recorded in predesigned and pretested Performa.

\section{Observation and results}

A total of 50 patients with fracture shaft of tibia treated with closed reamed intramedullary interlocking nailing was studied from December 2014 to march 2016. Blachut et al. [6] reported an infection rate of $0 \%$ in closed fractures in reamed nailing and $2 \%$ in closed fractures in unreamed nailing The patients are followed up for at least 10-12 months. All these patients were available for follow up. All the fractures united with a union rate of $94 \%$. Donald et al. ${ }^{[8]}$ reported a union time of 28 weeks in closed fracture treated by reamed nailing. Pre operatively following factors were observed and tabulated as follows.

Table 1: Incidence of tibial fractures according to age distribution

\begin{tabular}{|c|c|c|}
\hline Age group & No. of cases & Percentage \\
\hline $20-30$ & 18 & 36 \\
\hline $30-40$ & 16 & 32 \\
\hline $41-50$ & 9 & 18 \\
\hline$>51$ & 7 & 14 \\
\hline
\end{tabular}

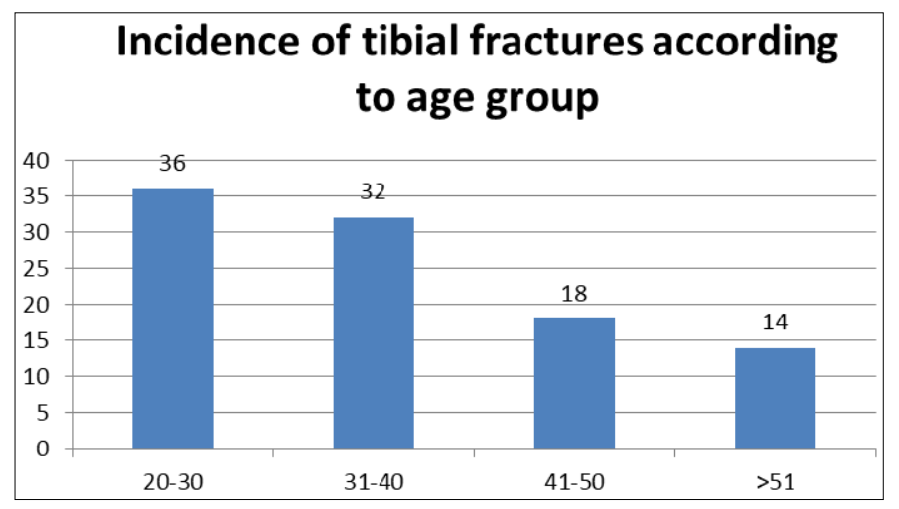

Table 2: Incidence according to sex

\begin{tabular}{|c|c|c|}
\hline Age group & No. of cases & Percentage \\
\hline Male & 36 & 72 \\
\hline Female & 14 & 28 \\
\hline
\end{tabular}

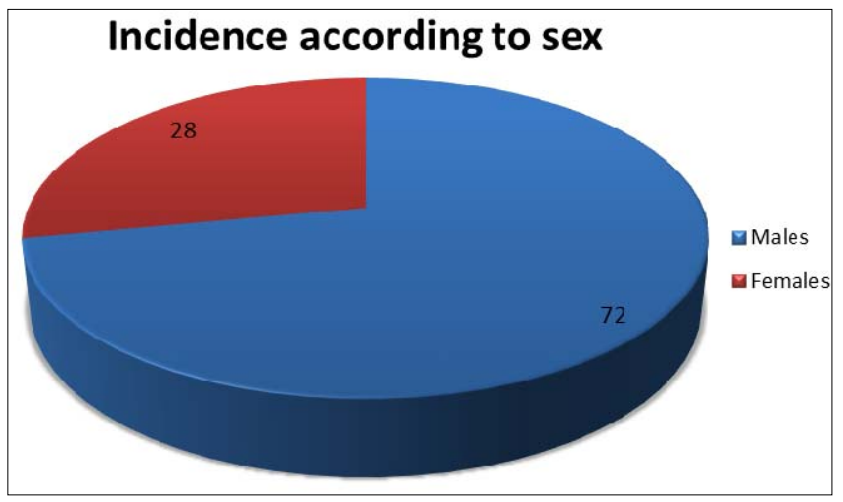

Table 4: Mode of injury

\begin{tabular}{|c|c|c|}
\hline Mode of injury & No of Cases & Percentage \\
\hline RTA & 35 & 70 \\
\hline Fall & 10 & 20 \\
\hline Assault & 5 & 10 \\
\hline
\end{tabular}

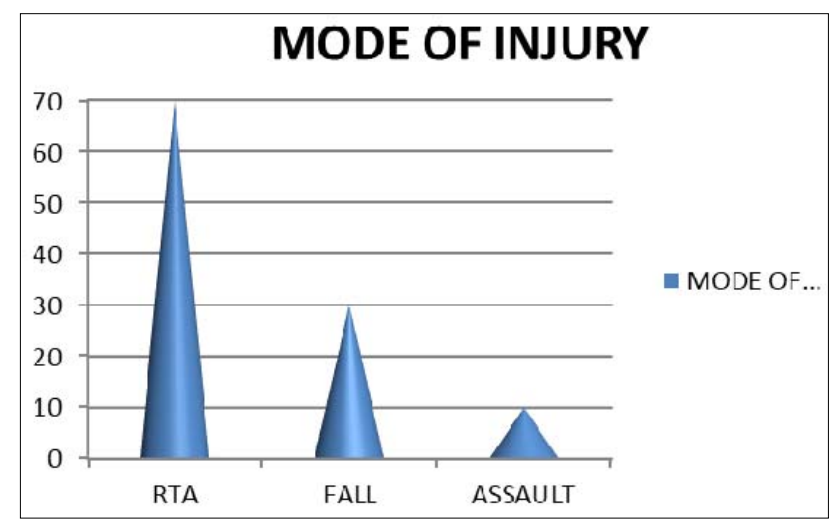

Nail size and locking: Majority of the nails inserted were $9 \mathrm{~mm}, 8$ nails were of $10 \mathrm{~mm}$ diameter and 4 were of $8 \mathrm{~mm}$ diameter. 42 fractures were locked in static mode and 8 fractures were locked dynamically.

Patient mobilization: All the cases were started with joint mobilization exercises on $1^{\text {st }}$ post operative day. Partial weight bearing was delayed till 6 weeks irrespective of fracture configuration. The average period of commencement of full weight bearing was 12.2 weeks.

Table 8: Patient Mobilization

\begin{tabular}{|c|c|c|}
\hline FWB & No. of Cases & Percentage \\
\hline 12 weeks & 42 & 84 \\
\hline 14 weeks & 5 & 10 \\
\hline$>14$ weeks & 3 & 6 \\
\hline
\end{tabular}

Range of motion: The average range of motion in the knee joint was 135.6 degree, full ankle motion was observed in 45 patients. Two patient showed a loss of $>25^{0}$ of motion at ankle compared to the normal side while 3 patients showed $<25^{0}$ of loss of joint motion.

\section{Duration of surgery}

In 50 patients, 40 patients ( $80 \%$ cases) the duration of surgery was less than 90 minutes, in 8 patients (16\% cases) the duration was $91-120$ minutes and in 2 patients (4\% cases) the duration was more than 120 minutes. Average operative time for all fractures was 83 minutes.

\section{Discussion}

Fifty cases of fractures of tibial shaft treated with reamed intramedullary interlocking nailing were studied from December 2014 to march 2016 forms the basis of the present study.

The average age of patients was 34.64 years with majority of patients under 35 years. There were 36 male patients and 14 female patients. Road Traffic Accidents were the main mode 
of injury accounting for $70 \%$ of cases.

In the present study, 30 fractures occurred on the right side and 20 fractures occurred on the left side and middle third of the tibia was involved in $60 \%$ of cases.

Thirty three fractures showed a transverse pattern, 17 were oblique. Most (84\%) of the cases were associated with ipsilateral fibula fractures. Transtendinous approach was used in all the 50 cases and reaming was performed in all the cases. The average diameter of the nails used was $9 \mathrm{~mm}$. 8 nails were dynamically locked. Dynamization was done in 8 cases. All the fracture united in the present study with a union rate of $96 \%$.

The demographic profile of our series is closely comparable to Court Brown et al, Toivanen et al. comparing our data with the previous series, we found similar results regarding union rates, outcome and complications.

\section{Conclusions}

This study comprised of 50 adult patients treated with intramedullary interlocking nail. Majority of the patients were in the age group of 20 years to 50 years of age. Males were affected more commonly than females, predominantly right side was involved. Road traffic accidents were the common mode of injury.

\section{References}

1. Court Brown CM, Christie J, McQueen MM. Closed intramedullary tibial nailing. J Bone and Joint Surg. 1990; 72-B (4):605-611.

2. Toivanen JAK, Vaisto O, Kannus P, Latvala K, Honkonen SE, Jarvinen MJ. Anterior knee pain after intramedullary nailing of fractures of the tibial shaft. A prospective, randomized study comparing two different nail insertion techniques. J Bone and Joint Surg. 2002; 84-A:580-585.

3. Thakur AJ. Intramedullary nailing. In: The elements of fracture fixations. $1^{\text {st }}$ Edn. New York: Churchill Livingstone, 1997, 81.

4. Hamza KN, Dunkerly GE, Murray MM. Fractures of the tibia-A report on fifty patients treated by intramedullary nailing. J Bone Joint Surg. 1971; 53B:696-700.

5. Bone LB, Johnson KD. Treatment of tibial fractures by reaming and intramedullary nailing. J Bone Joint Surg. 1986; 68A:877-87.

6. Blachut PA, O’Brien PJ, Meek RN, Broekhuyse HM. Interlocking intramedullary nailing with and without reaming for the treatment of closed fractures of the tibial shaft. A prospective, randomized study. J Bone Joint Surg. 1997; 79A:640-646.

7. Klemm KW, Borner $\mathrm{M}$. Interlocking nailing of complex fractures of femur and tibia. Clin Orthop. 1986; 212:89-100.

8. Wiss DA, Stetson WB. Unstable fractures of the tibia treated with a reamed intramedullary interlocking nail. Clin Orthop 1995; 315: 56-62.

9. Watson Jones R, Cottact WD. Slow union of fractures with a study of 804 fractures of the shaft of the tibia and femur. J Bone and Joint Surg. 1942; 30:260.

10. Charnley J. Fractures of the shaft of the tibia. In: The closed treatment of common fractures. $4^{\text {th }}$ Edn. Edinburgh: Churchill Livingstone, 1961, 205-249.

11. Dehne E, Metzent, Reffer PA. Non operative treatment of the fractured tibia by immediate weight bearing. $\mathrm{J}$ Trauma. 1961; 1:514.
12. Brown PW, Urban JG. Early weight bearing treatment of open fractures of the tibia:An end result of 65 cases. J Bone and Joint Surg (Am). 1969; 51:59-75.

13. Templeman DC, Benjamin G, Tsukayama DT, Gustilo $\mathrm{RB}$. Update on the management of open fractures of the tibial shaft. Clin Orthop. 1998; 350:18-25.

14. Ilizarov GA. Clinical application of the tension stressstress effect for limb lengthening. Clin Orthop. 1990; 250:8-26.

15. Bhandari M, Guyatt GH, Tong D, Adili A, Shaughnessy SG. Reamed versus non-reamed intramedullary nailing of lower extremity long bone fractures: A systematic overview and meta-analysis. J Orthop Trauma. 2000; 14:2-9.

16. Finkemeir CG, Schmidt AH, Kyle RF, Templeman DC, Varecka TF. A prospective, randomized study of intramedullary nails inserted with and without reaming for the treatment of open and closed fractures of the tibial shaft. J Orthop Trauma. 2000; 14:187-93.

17. Whittle AP, Russell TA, Taylor JC, Lavelle DG. Treatment of open fractures of tibial shaft with the use of interlocking nailing without reaming. J Bone Joint Surg. 1992; 74A:1162-1171.

18. Hamza KN, Dunkerly GE, Murray MM. Fractures of the tibia-A report on fifty patients treated by intramedullary nailing. J Bone Joint Surg. 1971; 53B:696-700.

19. Bone LB, Johnson KD. Treatment of tibial fractures by reaming and intramedullary nailing. J Bone Joint Surg. 1986; 68A:877-87.

20. Cohen HD. Proximal entry for intramedullary nailing of the tibia. The risk of unrecognized articular damage. $\mathrm{J}$ Bone and Joint Surg (Br). 2000; 82(1):.33-41.

21. Paige AW, William W, Russel TA. Fatigue failure in small diameter tibial nails. Clin Orthop. 1995; 315:119128.

22. Hutson JJ, Zych GA, Coe JD, Johnson KD, Osterman $\mathrm{P}$, Milne EL et al. Mechanical failure of intramedullary tibial nails applied without reaming. Clin Orthop. 1995; 315:129-137. 